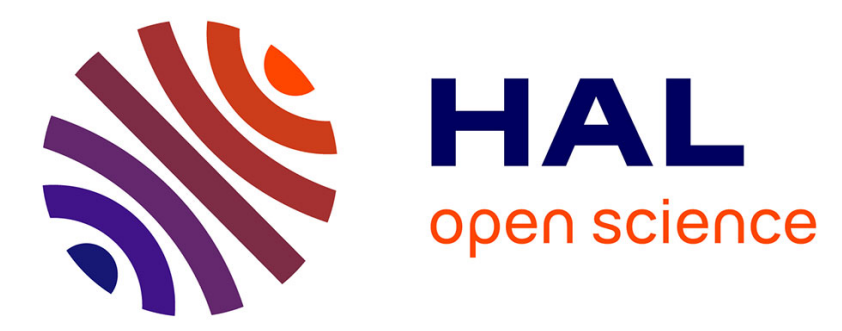

\title{
Archaeobiogeography of extinct rice rats (Oryzomyini) in the Lesser Antilles during the Ceramic Age (500 BCE-1500 CE)
}

Marine Durocher, Violaine Nicolas, Sophia Perdikaris, Dominique Bonnissent, Gwenola Robert, Karyne Debue, Allowen Evin, S. Grouard

\section{To cite this version:}

Marine Durocher, Violaine Nicolas, Sophia Perdikaris, Dominique Bonnissent, Gwenola Robert, et al.. Archaeobiogeography of extinct rice rats (Oryzomyini) in the Lesser Antilles during the Ceramic Age (500 BCE-1500 CE). The Holocene, 2021, 31 (3), pp.433-445. 10.1177/0959683620972785 . hal03045458

\section{HAL Id: hal-03045458 \\ https://hal.science/hal-03045458}

Submitted on 10 Dec 2020

HAL is a multi-disciplinary open access archive for the deposit and dissemination of scientific research documents, whether they are published or not. The documents may come from teaching and research institutions in France or abroad, or from public or private research centers.
L'archive ouverte pluridisciplinaire HAL, est destinée au dépôt et à la diffusion de documents scientifiques de niveau recherche, publiés ou non, émanant des établissements d'enseignement et de recherche français ou étrangers, des laboratoires publics ou privés. 


\section{Archaeobiogeography of extinct rice rats (Oryzomyini) in the}

\section{Lesser Antilles during the Ceramic Age (500 BCE to 1500 CE)}

3 Marine Durocher ${ }^{1,2,3+}$, Violaine Nicolas $^{2}$, Sophia Perdikaris ${ }^{4}$, Dominique Bonnissent ${ }^{5,6}$,

4 Gwenola Robert $^{5}$, Karyne Debue ${ }^{1}$, Allowen Evin ${ }^{3 *}$, Sandrine Grouard ${ }^{1 *}$

*contributed equally to the work

+corresponding author: marine.durocher@mnhn.fr

71 Laboratoire Archéozoologie, Archéobotanique: Sociétés, Pratiques, Environnements 8 (AASPE), Muséum national d'Histoire naturelle, CNRS, CP 56, 55 rue Buffon F-75231 Paris

9 Cedex 05, France.

102 Institut de Systématique, Evolution, Biodiversité (ISYEB), Muséum national d'Histoire 11 naturelle, CNRS, Sorbonne Université, EPHE, Université des Antilles, CP51, 57 rue Cuvier, 1275005 Paris, France.

$13{ }^{3}$ Institut des Sciences de l'Evolution - Montpellier (ISEM), CNRS, Université de Montpellier, 14 IRD, EPHE, 2 place Eugène Bataillon, CC065,34095 Montpellier, Cedex 5, France ${ }^{4}$ Anthropology, School of Global Integrative Studies, College of Arts and Sciences, University of Nebraska-Lincoln, 816 Oldfather Hall, P.O. Box 880368, Lincoln, NE 68588.

$17{ }^{5}$ Ministère de la Culture, Direction des affaires culturelles de Guadeloupe, Ministère de la 18 Culture, 28 rue Perrinon, 97100 Basse-Terre.

${ }^{6}$ Laboratoire Archéologie des Amériques (ArchAm), UMR 8096 CNRS, Université Paris 1 


\section{ABSTRACT}

During the Ceramic Age (500 BCE - $1500 \mathrm{CE})$, Lesser Antilles rice rats (Tribe Oryzomyini) made up a significant portion of the diet of Caribbean islanders. Archaeological excavations across the archipelago resulted to the discovery of large quantities of remains from to these now extinct taxa. It offers a unique opportunity to investigate the past biogeography of this taxon of high cultural and ecological importance. We have studied 1140 first lower molars originating from 40 archaeological sites across eleven islands of the Lesser Antilles archipelago using twodimensional geometric morphometric approaches to establish spatiotemporal patterns relying on phenotypic variations. This study identified three morphological groups, present in all chrono-cultural periods, that were geographically restricted and consistent with published ancient mitochondrial DNA clusters. These three geographically-separate groups likely represent three distinct genera of rice rats. The first group includes specimens from the North of the archipelago (Saint-Martin, Saba, Saint-Eustatius, Saint-Kitts and Nevis) and likely referable to as Pennatomys sp.; the second, occurring in the South (Martinique), is assigned to Megalomys desmarestii; and the third corresponds to specimens from the center of the Lesser Antilles (Antigua, Barbuda, Marie-Galante and Guadeloupe) and likely corresponds to Antillomys sp. These oryzomyine morphotypes are present during all studied periods and support an older presence of these rodents in the region. Our results are congruent with ancient DNA studies that favor the hypothesis of a natural introduction of the group in the archipelago before settlement of human populations. Moreover, the observed phenotypic homogeneity and stability over the 2000 years of Pre-Columbian occupation suggests that rice rats were not part of long-distance inter-island exchanges by humans. Instead, rice rat human consumption was likely based on in-situ hunting of local populations. 
1 Keywords: Caribbean archipelago - Bioarchaeology - Geometric morphometrics - Human

2 colonization - Island evolution - Late Holocene - Rodents - Teeth

\section{INTRODUCTION}

The Lesser Antilles are an oceanic archipelago in the Caribbean, located between two

biogeographic features, the Anegada passage off the Anguilla bank (Jany et al., 1990), and

Koopman's Line off the Grenada Bank (Genoways et al., 2010) (Fig. 1). The Lesser Antilles show a low diversity of terrestrial organisms associated with a high rate of endemism common to many island ecosystems (e.g. Baker \& Genoways, 1978; Bond, 1999; Hedges, 1999; Ricklefs \& Bermingham, 2007) which are profoundly influenced by both modern and past human activity (Whittaker and Fernández-Palacios, 2007). The first attested human settlement in the Lesser Antilles dates to the $4^{\text {th }}$ millennium BCE (Bonnissent et al., 2014) in Saint-Martin. Archaeological records confirm the ancient introduction and translocation of continental plants and animals that are still present today, including manioc (Manihot exculenta), maize (Zea mays), papaya (Carica papaya) (Newsom and Wing, 2004; Pagán Jiménez et al., 2005), dogs (Canis familiaris), and agouti (Dasyprocta sp.) (Bonnissent, 2008; Giovas et al., 2012, 2016; Wing, 2001a). Lesser Antillean rice rats (tribe Oryzomyini) are considered to be endemic to the archipelago, as the timing of their arrival in this area has been estimated via molecular clock analysis to the Late Miocene (6.814-6.303 Mya - Brace, Turvey, Weksler, Hoogland, \& Barnes, 2015). However, the oldest secure evidence of rice rats recovered from the paleontological record is contemporaneous with the earliest human occupations of the archipelago (Steadman et al., 1984). Rice rats are abundant in archaeological assemblages and show clear evidence of consumption (cutting and burning marks) (Grouard, 2007), though are now extinct across the 
1 1942; Ray, 1962). Traditional reasons for small mammal extinction on islands include the

2 introduction of competing species (MacPhee and Flemming, 1999) such as rats (Rattus rattus

3 and R. norvegicus) or new predators like the cat (Felis silvestris) (Henderson, 1992), the Small

4 Indian mongoose (Herperstidae, Urva auropunctata) (Grouard, 2001; Henderson, 1992; Horst

5 et al., 2001) and the racoon (Procyonidae, Procyon lotor) (Louppe et al., 2020), or overhunting

6 (Ray, 1962; Steadman et al., 1984; Trouessart, 1885), along with the transformation of the

7 landscapes and deforestation (Boudadi-Maligne et al., 2016). Yet the specific causes of rice rat

8 extinction in the Lesser Antilles still remains unclear.

Pre-Columbian societies relied primarily on marine resources such as fish and mollusks

(Grouard, 2010; Wing and Wing, 1995) but terrestrial mammals, including oryzomyines, were

also consumed as evidenced by the presence of butchery and burning marks on recovered remains (Grouard, 2004, 2010; Newsom and Wing, 2004; Wing, 2001b, 2001a). Rice rats were an important part of the human diet throughout the Ceramic Age. Analysis of zooarchaeological collection from the site of Hope Estate (Saint-Martin) show that rice rats comprise $54 \%$ of the total number of all identified vertebrates (NMI=748/1,384; Grouard, 2004). Extensive evidence for anthropic inter-island exchange in the Lesser Antilles has been evidenced for e.g. dogs, 17 humans, raw materials, and artefacts (i.e. Bonnissent, 2008; Bonnissent, 2013; Fitzpatrick, 2015; Hofman et al., 2006, 2007, 2008; Hofman and Hoogland, 2011; Knippenberg, 2007; Laffoon et al., 2013, 2015, 2016; Stouvenot and Randrianasolo, 2013). It is still unclear whether rice rats were part of this network. Anthropic translocation has been proposed for the group (LeFebvre and deFrance, 2014) and examplified by the presence of South American rice rats of the genus Zygodontomys in the island of Carriacou (Giovas, 2018; Mistretta, 2019).

Rodents have colonized a remarkable number of islands worldwide, either by natural dispersal (e.g. Fabre et al., 2013; Jansa et al., 2006), as stowaway like the black rat (Rattus 
1 like the domestic guinea pig (Cavia porcellus; Kimura et al., 2016; LeFebvre and deFrance,

2 2014; Lord et al., 2018). Morphological similarities between rodent populations can be used to

3 explore the type of dispersal (e.g. Cucchi et al., 2014; LeFebvre et al., 2019) along with the

4 impact of environmental factors on their diversity (e.g. Maestri et al., 2018).

5 In this study we have used tooth identification as the basis of our analysis. Teeth have an

6 advantage over other skeletal elements in that they are often well preserved, are recovered in

7 large numbers in the archaeological record and known to be taxonomically informative (Cucchi,

8 2009; Darviche et al., 2006; Darviche and Orsini, 1982; Renaud et al., 1996; van Dam, 1996).

9 Consequently, teeth, especially their size and shape have been used to study past rodent

10 populations and their relationship with human societies (e.g. Cucchi et al., 2014; Hulme-

11 Beaman et al., 2018b; Valenzuela-Lamas et al., 2011).

Because Lesser Antilles rice rats have no direct modern relatives and because morphological evolution of insular populations can happen very fast (Millien, 2006) eventually

14 leading to inter-island radiation (e.g. Kadmon and Allouche, 2007), the current systematic and taxonomy of the group is still not fully established. Three genera are currently recognized in the Lesser Antilles archipelago (Brace et al., 2015; Machado et al., 2014) (Fig. 1): Pennatomys has been described in the North of the archipelago (Saint-Eustatius, Saint-Kitts and Nevis) (Turvey et al., 2010), Megalomys (Trouessart, 1885) in the South (Martinique, Saint-Lucia and Barbados) (Forsyth Major, 1901; Friant, 1941; Miljutin, 2010), and Antillomys (Brace et al., 2015) in the center (Guadeloupe, Antigua and Barbuda) (Barbotin, 1970; Brace et al., 2015;

21 Hopwood, 1926; Pregill et al., 1994). These three genera are supported by high genetic divergence (560 bp of the Cytochrome $\mathrm{b}$ gene) and according to ancient genetic data Megalomys and Pennatomys are sister clades, only distantly related to the genus Antillomys (Brace et al., 2015). The present study aims to assess the archaeobiogeography of the oryzomyines taxa in the Lesser Antilles during the Ceramic Age and explore whether spatio- 
1 temporal variation in their morphology can be explained through human translocation. Results were compared to published ancient DNA clusters in order to gain in the understanding on the group taxonomy.

\section{MATERIALS}

\subsection{Chrono-cultural division}

The pre-Columbian archaeology of the Lesser Antilles is divided into two main periods: the Early and Late Ceramic Ages, each further divided into an early and a late phase. The Early Ceramic Age corresponds to the Saladoid cultures and it is divided into an early phase A (ECA) dating from c. 500 BCE to 400 CE (Early Cedrosan Saladoid and Huecan Saladoid), and a late phase B (ECB) from c. 400 to 600/800 CE (modified Cedrosan Saladoid, Late Saladoid, and Saladoid with Barrancoid influences) (Bérard, 2012; Fitzpatrick, 2015; Hofman et al., 2007, 2008). The Late Ceramic Age corresponds to the Troumassoid cultures and is divided into an A phase (LCA) dated from 600/800 to c. 1200 CE, and a B phase (LCB) dated from c. 1200 to 1500 CE. Contrary to the Early Ceramic, the two phases of Late Ceramic were characterized by a geographic division between the North and the South of the archipelago (Crock and Petersen, 2004; Mol, 2006; Rouse and Faber Morse, 1999; Siegel, 1989). The LCA is characterized by the Northern Troumassan Troumassoid and the Southern Suazan Troumassoid, while the LCB correspond to the Marmoran Troumassoid in the North and Troumassan Troumassoid in the South.

\subsection{Studied specimens}

A total of 1140 archaeological first lower molars $\left(\mathrm{M}_{1}\right.$, either isolated or enclosed in the mandible) belonging to adult specimens with limited wear were analyzed. When teeth were not 
1 found isolated, only hemi-mandibles were recovered and could not be left and right paired to

2 form complete jaws based on tooth wear abrasion or stratigraphic information, as a consequence

3 it is possible that both the right and left $\mathrm{M}_{1}$ of some specimens were included in the analyses.

4 Specimens originated from 40 archaeological sites spanning across the pre-Columbian Ceramic

5 Age in eleven islands throughout the archipelago (Fig. 1; Table 1). Specimens were assigned

6 to chronological cultural phases based on primary publications and excavation reports, and

7 according to investigators' opinion (Table 1; SI.1).

8

9 on the Procrustes residuals (coordinates after superimposition).

\section{METHODS}

\subsection{Morphometrics}

Photographs of the occlusal view of the lower first molar were taken using a LEICA 76 APO macroscope and a non-distorting objective, with a $1.25 \mathrm{x}$ or $1.6 \mathrm{x}$ magnification and Leica Microsystem LAS software (V4.8). A sliding semi-landmark based geometric morphometric approach was employed to quantify the size and the shape of the teeth. On each photograph, the two-dimensional coordinates of one landmark, placed at the junction between the most posterior point of the metaconid and the external buccal edge of the tooth were recorded, along with 65 equidistant sliding semi-landmarks localized along the external edge of the tooth (recorded clockwise) (Fig. 2) using TPS Dig2 (Rohlf, 2004). All photographs and measurements were taken by the same person (M.D.). Coordinates were superimposed using a generalized Procrustes analysis (GPA) (Goodall, 1995; Rohlf and Slice, 1990), with the semilandmarks allowed to slide following the Procrustes distance minimization criterion. Analyses of size were based on the log-transformed centroid size, and investigation of shape performed 6 


\subsection{Statistics}

Prior to analyses, the existence of size or shape clusters at each archaeological site, island, island bank, and overall was examined using a Gaussian Mixture Modelling for Model-Based Clustering (R package 'mclust,' Scrucca, 2016). This approach determines, based on a maximized loglikelihood approach, the number of clusters (i.e. groups) present in the dataset, without a priori knowledge.

Centroid size differences between populations from different sites, periods, islands and island banks were tested with Kruskal-Wallis and Wilcoxon tests and visualized by boxplots. In pairwise comparisons, p-values were adjusted using a Benjamini-Hochberg multicomparison procedure (Benjamini and Hochberg, 1995).

The shape variation was examined through the application of principal component analysis (PCA), before testing differences between groups through multivariate analysis of variance (MANOVA). Because of the large number of variables compared to the relatively low number of specimens per group, a dimensionality reduction of the data was performed (Baylac and Friess, 2005; Evin et al., 2013). Canonical variate analysis (CVA) and MANOVAs were performed on the firsts PCA scores that maximized the between-group discrimination quantified by leave-one-out cross validation (Baylac and Friess, 2005; Dobigny et al., 2002). CVA was used to quantify and visualize the group differences (Albrecht, 1980; Gittins, 1985; Russell et al., 2000). The discrimination power of the CVA was quantified by the mean crossvalidation percentage (CVP) and the 90\% confidence interval obtained from 100 CVAs performed on resampled same-size datasets (Evin et al., 2013). This approach randomly subsamples the largest groups to the size of the smallest group, thus removing effects of unbalanced sample size which is common and largely inevitable in bioarchaeology (Evin et al., 2013). Cross-validation percentages were calculated for size, shape and form (size+shape). In addition 
1 to CVA, phenotypic dissimilarity between groups were assessed using both Mahalanobis and

2 Procrustes distances. Distances were computed only for groups of at least 10 specimens and the

3 repeatability of the topologies was estimated by bootstrap with 1000 replicates. Procrustes

4 distances between group mean shape was obtained following Nagorsen and Cardini (2009) and

5 Mahalanobis distances were obtained from resampled datasets with equal number of specimens

6 per group. For both approaches the number of resampled specimens match the number of

7 specimens in the smallest group. The majority-rule consensus and mean branch lengths

8 topologies were computed as unrooted Neighbor-Joining (NJ) networks (Friesen et al., 2007;

9 Saitou and Nei, 1987) on which the percentage of trees in which each observed node grouping

10 appeared has been reported (i.e. bootstrap supports). All analyses were performed in R version

11 3.5.3 (R Core Team, 2019), with the 'ape' (Paradis and Schliep, 2018), 'Morpho' (Schlager,

12 2013) and 'Geomorph' (Adams et al., 2018) packages.

14 4. RESULTS

None of the clustering analysis on size and shape revealed the presence of multiple groups.

As a consequence, the composition of each archaeological site was considered homogeneous.

Despite the fact that the number of teeth per site and chrono-cultural period was maximized by including right and left teeth, statistical analyses were highly constrained by the number of specimens per site and chrono-cultural period. As a precaution, a subset of analyses were performed for teeth of only one side (left) of the mandible and provide congruent results though based on much less groups (for homogeneity groups with less than 10 specimens were excluded). Analyses performed in this study were constraint by available archaeological data which range from an island with only one site occupied during one period (e.g Saint-Kitts) to islands occupied during all periods on multiple sites (e.g. Martinique). 


\subsection{Main archaeobiogeographic pattern}

Analysis of the populations from each site and each cultural time period revealed three geographically structured clusters (figs. $3 \& 4$ ).

$<$ Figure 3 $>$

$<$ Figure $4>$ (

Molar centroid size analysis revealed two main clusters, perfectly discriminated, with the specimens from the Northern islands (Saint-Martin, Saba, Saint-Eustatius, Saint-Kitts and Nevis) showing much smaller teeth than any other specimens from across the archipelago (Fig. 3).

Shape analysis revealed differences between the populations $(F(46,2238)=105.91, p \leq 2.2 \mathrm{e}-$ 16). While Procrustes distances do not provide a resolved network topology (most bootstrap values are $<50 \%$ ) (SI.2), Mahalanobis networks (Fig. 4, SI.2) revealed three perfectly supported clusters (100\% bootstrap values) that are geographically structured. The first cluster corresponds to the northern islands (Saint-Martin, Saba, Saint-Eustatius, Saint-Kitts and Nevis), the second to the central islands (Barbuda, Antigua, Grande-Terre and Basse-Terre of Guadeloupe, and Marie-Galante) while the third correspond the southern island of Martinique. However, when working at the island scale (SI.2) the split between Martinique and the central islands is not supported, but because of the relatively long length of the Martinique branch and the high size differences between the two geographic clusters (Fig. 3) they were considered as valid morphometric and geographic entities. The paired leave-one-out cross validation between the three geographic clusters is high (94.4 \%; CI: 92.9 - $95.9 \%)$ confirming their morphometrical distinction. Moreover, when molar form is analyzed, combining size and shape data, this percentage reaches $99.7 \%$ (CI: 99.3 - $100 \%$ ). 


\subsection{Regional spatio-temporal patterns}

Variation within the three clusters was then investigated at different geographical and

4

chronological scales by looking at the differences between island banks (during past low-stand sea levels occurrences), between islands and sites, and through the different cultural time periods.

\subsubsection{The five northern Islands}

0 Populations from the five northern islands differ in both size $\left(X^{2}=147.5, \mathrm{df}=4, \mathrm{p} \leq 2.2 \mathrm{e}-16\right.$; $\mathrm{CVP}=35 \%(\mathrm{CI}: 28.8-43.8 \%) ;$ SI.3.2) and shape $(\mathrm{F}(44-2528)=11.8, \mathrm{p} \leq 2.2 \mathrm{e}-16 ; \mathrm{CVP}=51.1 \%$ (CI:41.3-58.8\%); SI.3.1-2) (Fig. 5). The island structuring of the populations observed in the networks (Fig. $4 \& 5$ ) is also evidenced by pairwise comparisons (SI.3.2). The differences between islands exceed the differences between cultural time periods despite the small number of populations available for comparison. Only Saint-Martin is represented by more than one period with sufficient specimens for a diachronic comparison. One site (Hope Estate) was occupied during the ECA and ECB, and the corresponding specimens differ only slightly in shape $(\mathrm{F}(4,517)=4, \mathrm{p}=3 \mathrm{e}-3 ; \mathrm{CVP}=55.7 \%(\mathrm{CI}: 50.5-59.9 \%))$ and not in size $(\mathrm{W}=22975, \mathrm{p}=0.3$; $\mathrm{CVP}=49.1 \%$ (CI:46.8-53.2\%)). On the other hand, differences between islands during the ECB are highly significant in both size $\left(\mathrm{X}^{2}=106.3, \mathrm{df}=3, \mathrm{p} \leq 2.2 \mathrm{e}-16 ; \mathrm{CVP}=39.7 \%(\mathrm{CI}: 29.7-48.4 \%)\right.$;

SI.3.2) and shape $(\mathrm{F}(24-1533)=15.5, \mathrm{p} \leq 2.2 \mathrm{e}-16 ; \mathrm{CVP}=57.8 \%(\mathrm{CI}: 40.9-65.7 \%) ;$ SI.3.1-2).

\section{$<$ Figure 5>}


In Martinique, the populations differ in both size $\left(\mathrm{X}^{2}=19.5, \mathrm{df}=5, \mathrm{p}=0.0015 ; \mathrm{CVP}=23.5 \%\right.$

2 CI:5.6-38.9\%) $)$ and shape $(\mathrm{F}(85,355)=2.2, \mathrm{p}=4 \mathrm{e}-7$; $\mathrm{CVP}=27.9 \%(\mathrm{CI}: 11.1-44.4 \%))$. Specimens

3 from the Early and Late Ceramic differ in shape $(\mathrm{F}(14,64)=3.9$, $\mathrm{p}=8 \mathrm{e}-5$; $\mathrm{CVP}=71.7 \%$ (CI:64.8-

4 79.6\%); SI.4.1-2), but not in size (W=707, $\mathrm{p}=1$; $\mathrm{CVP}=35.2 \%$ (CI: 3.6-51.9\%), SI.4.2). The

5 specimens from the ECB populations do not differ in size $\left(X^{2}=4, d f=2, p=0.1\right)$ or shape

$6 \quad(F(16,36)=1.7, p=0.1)$. During the $\mathrm{LCB}$, there was no observed size difference, $(\mathrm{W}=257$,

$7 \mathrm{p}=0.94)$, but shape varied $(\mathrm{F}(8,38)=2.6, \mathrm{p}=0.02 ; \mathrm{CVP}=64.5 \%(\mathrm{CI}: 55.6-75 \%))$.

\subsubsection{The five Central islands}

The populations from the central islands differ in both size $\left(\mathrm{X}^{2}=105.4, \mathrm{df}=4, \mathrm{p}<2.2 \mathrm{e}-16\right.$; $\mathrm{CVP}=32.6 \%(\mathrm{CI}: 28.1-37.8 \%))$ and shape $(\mathrm{F}(100,1536)=4.4, \mathrm{p} \leq 2.2 \mathrm{e}-16 ; 44.7 \% \quad(\mathrm{CI}: 38.5-$ $51.2 \%)$ ). Only populations from Barbuda and Guadeloupe Basse-Terre are clustered by islands (only one population was studied from Antigua) contrary to the populations from Grande-Terre and Marie-Galante (Fig. 6).

$<$ Figure 6 $>$

Specimens from the two islands of the Barbuda bank (Antigua and Barbuda) differ from each other in shape $(\mathrm{F}(7,61)=3.1, \mathrm{p}=0.007$; $\mathrm{CVA}=65.6 \%$ (CI:59.3-72.2\%); SI.5.1) but not in size $(\mathrm{W}=454, \mathrm{p}=0.2)$. Specimens from the three archeological sites from Antigua (SI.5.1-2), all attributed to the LCA, differ in shape $(\mathrm{F}(16,36)=2.1, \mathrm{p}=0.03 ; \mathrm{CVA}=41.4 \%(\mathrm{CI}: 22.2-66.7 \%))$

22 but not in size $\left(\mathrm{X}^{2}=1.49, \mathrm{df}=2, \mathrm{p}=0.47\right)$. On Barbuda, the specimens from the two sites (one ECA, one LCA $)$ do not differ in their molar size $(\mathrm{W}=170$, $\mathrm{p}$-value $=0.2)$ nor shape $(\mathrm{F}(3,38)=0.3$, $\mathrm{p}=0.9)$. 
Thirteen sites were analyzed from the Guadeloupe Bank (Basse-Terre + Grande-Terre,

2 Table 1; SI.5.1-2). On average, specimens from Basse-Terre have larger molars than those from

3 Grand-Terre $(\mathrm{W}=6398, \mathrm{p}=5.4 \mathrm{e}-11, \mathrm{CVP}=71.1 \%(\mathrm{CI}: 68.8-73.6 \%))$ and differ slightly in shape $4 \quad(\mathrm{~F}(15,169)=4.2, \mathrm{p}=1 \mathrm{e}-6 ; \mathrm{CVP}=50.2 \%(\mathrm{CI}: 41.6 \%-58.4)$. On Grande-Terre, the specimens from 5 the different sites do not differ in size $\left(X^{2}=5.5, \mathrm{df}=6, \mathrm{p}=0.5\right)$, but differ in shape $(\mathrm{F}(78,588)=1.4$, $6 \mathrm{p}=0.02 ; \mathrm{CVP}=28.4 \%(\mathrm{CI}: 14.3-50 . \%))$. During the ECA the populations do not differ in either 7 size $(\mathrm{W}=41, \mathrm{p}=0.7)$ or shape $(\mathrm{F}(5,11)=1.4, \mathrm{p}=0.3)$, nor do they differ during the LCA (size: $8 \mathrm{X}^{2}=2.2, \mathrm{df}=4, \mathrm{p}=0.7$; shape: $\left.\mathrm{F}(36,64)=1.2, \mathrm{p}=0.2\right)$. However, specimens attributed to the Early and Late Ceramic differ in shape $(\mathrm{F}(6,103)=4.2, \mathrm{p}=0.0008 ; \mathrm{CVP}=67.8 \%(\mathrm{CI}=64.5-71.9 \%)$ but not in size $(\mathrm{W}=1317, \mathrm{p}=0.3)$.

Similarly to the ones from Grande-Terre, Basse-Terre populations differ in shape $(\mathrm{F}(115,240)=1.4, \mathrm{p}=0.02 ; \mathrm{CVP}=22.8 \%(\mathrm{CI}: 12.3-33.5 \%))$, but not in size $\left(\mathrm{X}^{2}=4.9, \mathrm{df}=5, \mathrm{p}=0.4\right)$.

Finally and again similarly, in Marie-Galante, the populations do not differ in size $\left(\mathrm{X}^{2}=6.2\right.$, $\mathrm{df}=9, \mathrm{p}=0.7)$ but differ in shape $(\mathrm{F}(66,816)=2.03, \mathrm{p}=6.1 \mathrm{e}-06) ; \mathrm{CVA}=24.6 \%(\mathrm{CI}: 16.1-33.9)$; SI.5.1-2). Specimens attributed to the Early and Late Ceramic differ in shape $(F(12,143)=3.31$, $\mathrm{p}=0.0003 ; \mathrm{CVP}=63 \%(\mathrm{CI}: 59.5-66.3 \%)$, but not in size $(\mathrm{W}=2646, \mathrm{p}=0.2)$. We detect no differences between the ECA and ECB (size: $X^{2}=1.1, d f=1, p=0.29$; shape: $F(16,66)=1.1$, $p=0.4)$ whereas specimens differ in shape between the LCA and $\operatorname{LCB}(F(2,70)=5.5, p=0.006$; $\mathrm{CVP}=65.1 \%(\mathrm{CI}=50-81.3 \%))$, but not size $(\mathrm{W}=323, \mathrm{p}=0.3$; SI.5.1-2 $)$.

\section{DISCUSSION}

Three morphometric clusters, corresponding to three biogeographic units, were identified from the molar size and shape variation: one in Martinique in the south, one in the center islands of the archipelago (Barbuda, Antigua, Guadeloupe, and Marie-Galante), and one in the 
1 Morphological distances between island cannot be explained by the geographic distances

2 between them since some geographically close islands are distant morphometrically (e.g.

3 Antigua (central cluster) is $83 \mathrm{~km}$ far from Nevis (northern cluster), and $106 \mathrm{~km}$ far from Basse-

4 Terre (central cluster)).

This geographic variation greatly outweighs temporal variation, with only slight differences in molar morphology linked to cultural time periods within each geographical cluster. Our results thus support long term biogeographic patterning of morphological variation over the span of ca. 2,000 years.

\subsection{Morphological diversity and rice rat taxonomy}

By only working on the first lower molars only a small portion of the entire phenotype of the organism is quantified. However, teeth are the most abundant rodents remains in archeological or paleontological sites, and they are widely used to infer the systematic, taxonomy and spatio-temporal patterns in this group (e.g. Hulme-Beaman et al., 2018a; Stoetzel et al., 2017). Tooth morphology is the result of both an adaptive and an heritability component (Bader, 1965; Polly and Mock, 2018; Renaud et al., 2006). Given the absence of genetic and morphometric data on exactly the same specimens, which make it impossible to draw definitive conclusions on the taxonomy of rice rats, the strong biogeographic patterning observed in tooth morphology could nonetheless be used to infer the diversity of Antillean rice rats and discuss taxonomical attributions. Our results reveal three distinct morphotypes likely corresponding to the three genera previously described in earlier morphometric and ancient DNA research (Brace et al., 2015; Turvey et al., 2010). The Martinican archaeological specimens (89 specimens) likely correspond to Megalomys desmarestii (Fischer, 1829), the only species described from the island (Friant, 1941; Trouessart, 1885) and for which only four specimens have been molecularly analyzed (Brace et al., 2015). Megalomys luciae (Forsyth Major, 1901) specimens 
1 from Sainte-Lucia were not included in this study. However, specimens from Barbuda, where

2 Megalomys audreyae was previously described (Hopwood, 1926), were found to be

3 morphologically closer to specimens from the central islands, including Grande-Terre and

4 Antigua, where Antillomys rayi was genetically identified (Brace et al., 2015). The slight

5 morphometric differences revealed by our analyses ( 407 specimens) between the central islands

6 may correspond to intra-specific variation within Antillomys rayi although the possibility that

7 our sample includes several distinct species (with morphometrically closely similar first lower

8 molars) could not be excluded. Finally, the third cluster including specimens from the Northern

9 islands (644 specimens) likely corresponds to Pennatomys, with Pennatomys nivalis described

10 from the Saint-Kitts Bank (Turvey et al., 2010). Brace et al. (2015), based on the Cytochrome

11 b mitochondrial gene, observed some genetic differentiation between islands across the Saint-

12 Kitts Bank, with $2 \%$ of genetic divergence between specimens from Nevis and Saint-Kitts, and

$13 \quad 5-7 \%$ divergence between these specimens and those from Saint-Eustatius. These molecular

14 analyses are in perfect agreement with our morphometrical data (specimens from Nevis and

15 Saint-Kitts being morphological closer than those from Saint-Eustatius) and suggest

16 intraspecific or inter-specific variation. Our results suggest that the two geographically-distant

17 island groupings, Martinique in the South and the Northern islands, are phenotypically more

18 similar to each other, than to those of the geographical closer central islands. This is consistent

19 with molecular data showing a sister relationship between Megalomys and Pennatomys, while

20 Antillomys is more distantly related (Brace et al., 2015). Further research on this insular group

21 taxonomy should seek to combine morphometric analysis with ancient DNA of the same

22 specimens, in order to confirm the taxonomy of all investigated populations. 
Rice rats from the Northern islands had very small molar size compared to the rest of the

2 archipelago. A similar pattern has been observed in the Anolis lizards from Saint-Martin which

3 particularly small size has been linked to the presence of competition (Brown and Wilson, 1956;

4 Losos, 2000; Losos and Ricklefs, 2009; Roughgarden, 1995). Accordingly, the size of the

5 oryzomyines from Saint-Martin and the other northern islands might be caused by the presence

6 of a competitor species (e.g. Amblyrhiza inundata identified in the Anguilla bank during the

7 Pleistocene; McFarlane et al., 2014) or by the existence of peculiar, but yet to be determined,

8 local conditions which impacted species size on these islands.

In the present study comparison between chrono-cultural periods was greatly limited by the number of archaeological sites available for each island and period. Despite these limitations, we detected some differences in shape, but not in size, between diachronic populations, more especially between the Early and Late Ceramic in Martinique, Marie-Galante, and Guadeloupe Grande-Terre. Diachronic differentiation between archaeological rodent populations have been identified, in other species, using a similar methodology (e.g. Cucchi et al., 2014; HulmeBeaman et al., 2018b) and has been interpreted as the result of a variety of causes including human landscape modification, climatic change, or a combination of both causes.

In the case of oryzomyine, their past and current distribution ranges on the South American continent indicates that climatic change has affected their distribution (Vázquez-Domínguez et al., 2020; Vickery et al., 2016). In the Lesser Antilles archipelago, a climatic change is registered around 900-1000 CE, and coincide to the transition between the Early and Late Ceramic Age. This change is linked with a transformation from a wet to a dryer and stormier climate across the archipelago (Beets et al., 2006; Bertran et al., 2004). In between these two periods, Pre-Columbian populations also experienced societal changes, identifiable in material

24 culture and habitat (Fitzpatrick, 2015; Hofman et al., 2007; Siegel et al., 2015) and 
1 bioarchaeological studies point to a transformation in the management and consumption of

2 resources (Grouard, 2004, 2007, 2010; Wing, 2001a).

3 If these elements are to be considered, further investigations are required to define the 4 impact of ecological factors on insular rice rat morphology, which is particularly challenging 5 when dealing with extinct taxa.

6

\subsection{No strong evidence for human-mediated dispersal}

A proposed northward river-based connection between the Amazon basin and the Caribbean sea during the late Miocene (Wilkinson et al., 2010) may have facilitated broadly simultaneous overwater dispersal of many South American mainland vertebrates to the Lesser Antilles (review in Brace et al., 2015). For instance, the genus Leptodactylus (Anura, Leptodactylidae) is considered to have colonized the Lesser Antilles by dispersal across water in the midCenozoic (Camargo, Heyer, \& de Sá, 2009; Hedges \& Heinicke, 2007). According to genetic data the multiple colonization events of oryzomyine in the archipelago date to the same period (late Miocene) (Brace et al., 2015), despite their absence in the paleontological records (Grouard, 2015). Our results show only slight phenotypic changes through archaeological chrono-cultural periods, between $500 \mathrm{BCE}$ and $1500 \mathrm{CE}$, as well as the continuous presence of three clearly defined geographic clusters supporting the hypothesis of an ancient arrival of the group in the archipelago.

Prior to their extinction, the rice rats of the Lesser Antilles lived close to human settlements and crop areas (Allen, 1942; Pinchon, 1967; Trouessart, 1885; Wing, 2001b). This tendency to commensalism was probably established since the first human occupation in the archipelago. Indeed, zooarchaeological studies highlight their importance in the subsistence economy of local human population throughout the entire Ceramic Age (Grouard, 2004, 2010; Wing, 2001b) and thus long-term interactions between these rodents and the Pre-Columbian 
1 populations. On the other hand, in the north of the archipelago the morphometric variation is

2 well structured per island, a pattern that favor a hypothesis of no (or at least not strong) inflow

3 from external rice rats populations that would have disrupted or smoothed out the inter-island

4 phenotypic structure. In the center, the differences between island phenotypes is less structured,

5 and the possibility of inter-island connections cannot be completely excluded. However, study

6 of additional specimens and archaeological sites would be necessary to confirm these

7 hypotheses. As the prevailing morphometric variation is geographically structured through time we suggest an absence of long-distance connection between islands from the different clusters, and thus an absence of human transport of oryzomyines from one island to another.

Moreover, rice rats fail to meet five of the 10 criteria proposed for classifying species as impacted by humanly-mediated translocations (Giovas, 2019; Heinsohn, 2003, 2010), and two of them could not be applied to this study. Even though the presence of oryzomyines is lacking in the paleontological and archaeological faunal records (criteria 2) prior to the Ceramic Age where they abruptly appear (criteria 3) (Grouard, 2015), they likely colonized the Lesser Antilles during the late Miocene (Brace et al., 2015). Rice rats show commensal tendency (criterion 5) on the continent (Guilday, 1972; Guilday and Parmalee, 1965; Vickery et al., 2016) and are found in zooarchaeological contexts in association with a plethora of naturally dispersed species (criterion 8) consumed by humans (Grouard, 2004, 2010; Newsom and Wing, 2004; Wing, 2001b), as well as with the agouti, another rodent potentially introduced (Allen, 1942; Newsom and Wing, 2004) and managed (Govoni and Fielding, 2001; Hardouin, 1995) 21 (criterion 7). At the scale of the archipelago, their distribution is wide (criterion 4), their phenotypic and molecular differentiation is geographically cohesive (criterion 1) and interisland differences persist through time (criterion 6, applied here to morphometric data). Finally,

24 the criteria based on comparisons with historically documented species introduction (criterion 9) and diachronic reconstruction of invasion frontiers (criterion 10) cannot be applied due to 
1 data limitation. Overall, the evidence from previous analyses alongside our current research

2 favors a non-anthropic dispersion of the group into the archipelago, or if contacts have existed,

3 newly human-introduced populations from one island to another have not persisted and were

4 not detected.

5

\section{CONCLUSIONS}

This study significantly contributes to our knowledge and understanding of the past

8 diversity of the tribe Oryzomyini in the Lesser Antilles archipelago. Over a thousand specimens

9 of these now extinct taxa were analyzed using geometric morphometrics, allowing the first exploration of their archaeobiogeography. The rice rats show diverse but very homogenous

11 molar morphotypes defined by geographic parameters, which remain largely stable for the 2.000 years of the Ceramic Age in the Lesser Antilles archipelago. The persistence of this strong archaeobiogeographical phenotypic pattern throughout the Ceramic Age supports a scenario of a pre-human dispersal of Oryzomyini species. While rice rats were a component of human diet throughout the Ceramic Age, our overall results do not support an initial hypothesis of humanmediated transport of rice rats between and within the three geographic entities, despite the

17 evidences of transportation of cultivated plants, domesticated animals and raw materials. Additional studies combining geometric morphometric and ancient DNA analyses on the exact same specimens would allow for the consolidation of the archaeobiogeography, taxonomy and systematics of these extinct endemic rodents, and better identify the environmental adaptations that might have driven the establishment of rice rat populations across the archipelago.

\section{ACKNOWLEDGEMENTS}

24 We would like to acknowledge the Guadeloupe (including Saint-Martin) and Martinique 
1 Antigua and Barbuda National Parks and the Barbuda Research Complex (BRC), and the

2 Florida Museum of Natural History in Gainesville (FLMNH) who provided the archaeological

3 specimens studied. We acknowledge the morphometric platform of the MNHN, Paris (UMS

4 OMSI). This work was granted by the ATM Blanche program of the MNHN, and the PEPS

5 ECOMOB grant of the CNRS, INEE. We would also like to acknowledge Alex Chepstow-

6 Lusty for language editing, and Carly Ameen, Ashleigh Haruda, Pierre-Henri Fabre, Pierre-

7 Olivier Antoine, and the team of the GAARAnti project for discussion and suggestions. We

8 warmly also thank Andrea Cardini and all the anonymous reviewers who gave helpful

9 comments on earlier versions of the manuscript.

\section{REFERENCES}

12 Adams DC, Collyer ML and Kaliontzopoulou A (2018) Geomorph: Software for geometric 13 morphometric analyses. $\mathrm{R}$ package version 3.0.1. https://cran.r-

14 project.org/package= geomorph.

15 Albrecht GH (1980) Multivariate analysis and the study of form, with special reference to 16 canonical variate analysis. American Zoologist 20(4): 679-693.

17 Allen GM (1942) Extinct and Vanishing mammals of the Western Hemisphere. Lancaster, 18 Pensylvania: The Intelligencer Princting Co.

19 Bader RS (1965) Heritability of dental characters in the house mouse. Evolution. JSTOR 378$20 \quad 384$.

21 Baker R and Genoways H (1978) Zoogeography of Antillean Bats. Mammalogy Papers:

22 University of Nebraska State Museum.

23 Barbotin PM (1970) Les sites archéologiques de Marie-Galante (Guadeloupe). Proceedings of 24 the Third International Congress for the Study of Pre-Columbian Cultures of the Lesser Antilles $25 \quad 27-44$. 
1 Baylac M and Friess M (2005) Fourier descriptors, Procrustes superimposition, and data

2 dimensionality: an example of cranial shape analysis in modern human populations. Modern 3 morphometrics in physical anthropology 145-165.

4 Beets CJ, Troelstra SR, Grootes PM, Nadeau M-J, Borg K v, de Jong AF, et al. (2006) Climate 5 and pre-Columbian settlement at Anse à la Gourde, Guadeloupe, Northeastern Caribbean. 6 Geoarchaeology 21(3): 271-280.

7 Benjamini Y and Hochberg Y (1995) Controlling the false discovery rate: a practical and 8 powerful approach to multiple testing. Journal of the royal statistical society. Series $B$ 9 (Methodological) 289-300.

10 Bérard B (2012) Pre-Columbian Antillean civilizations in an archipelagic perspective. paper 11 presented at the 1 st Garifuna International Conference. Available at: https:/hal.univ12 antilles.fr/hal-00961357/document.

13 Bertran P, Bonnissent D, Imbert D, Lozouet P, Serrand N and Stouvenot C (2004) Paléoclimat 14 des Petites Antilles depuis 4000 ans BP : l'enregistrement de la lagune de Grand-Case à SaintMartin. Comptes Rendus Geoscience 336(16): 1501-1510: doi:10.1016/j.crte.2004.09.009.

16 Bond J (1999) A Field Guide to the Birds of the West Indies. Houghton Mifflin Harcourt.

17 Bonnissent D (2008) Archéologie précolombienne de l'île de Saint-Martin, Petites Antilles 18 (3300 BC-1600 AD). PhD Thesis, Université de Provence-Aix-Marseille I.

Bonnissent D, Serrand N, Bruxelles L, Fouéré P, Grouard S, Sellier-Ségard N, et al. (2014) 20 Archéoécologie des sociétés insulaires des Petites Antilles au Mésoindien: 1'enjeu des 21 ressources à Saint-Martin. Séance de la Société préhistorique française de Rennes, 213-260.

22 Bonnissent (Dir.) D (2013) Les gisements précolombiens de la Baie Orientale: campements du 23 Mésoindien et du Néoindien sur l'île de Saint-Martin (Petites Antilles). Éditions de la Maison 24 des sciences de l'homme. 
1 Boudadi-Maligne M, Bailon S, Bochaton C, Casagrande F, Grouard S, Serrand N, et al. (2016)

2 Evidence for historical human-induced extinctions of vertebrate species on La Désirade (French

3 West Indies). Quaternary Research 85(1): 54-65.

4 Brace S, Turvey ST, Weksler M, Hoogland ML and Barnes I (2015) Unexpected evolutionary 5 diversity in a recently extinct Caribean mammal radiation. Proceedings Royal Society 6 publishing $B$ 282: 9.

7 Brown WL and Wilson EO (1956) Character displacement. Systematic zoology 5(2): 49-64.

8 Camargo A, Heyer WR and de Sá RO (2009) Phylogeography of the frog Leptodactylus validus

9 (Amphibia: Anura): patterns and timing of colonization events in the Lesser Antilles. Molecular 10 Phylogenetics and Evolution 53(2): 571-579.

11 Crock JG and Petersen JB (2004) Inter-island exchange, settlement hierarchy, and a Tainorelated chiefdom on the Anguilla Bank, Northern Lesser Antilles. Late Ceramic Age Societies 13 in the Eastern Caribbean. Eric Taladoire, 139-158.

14 Cucchi T (2009) Le commensalisme de la souris et les sociétés néolithiques méditerranéennes. 15 Collège de France.

16 Cucchi T, Barnett R, Martínková N, Renaud S, Renvoisé E, Evin A, et al. (2014) The changing 17 pace of insular life: 5000 years of microevolution in the Orkney vole (Microtus arvalis orcadensis). Evolution 68(10): 2804-2820.

Darviche D and Orsini P (1982) Critères de différenciation morphologique et biométrique de 20 deux espèces de souris sympatriques: Mus spretus et Mus musculus domesticus. Mammalia $21 \quad 46(2): 205-218$.

22 Darviche D, Orth A and Michaux J (2006) Mus spretus et M. musculus (Rodentia, Mammalia) 23 en zone méditerranéenne: différenciation biométrique et morphologique: application à des 24 fossiles marocains pléistocènes/Mus spretus and M. musculus (Rodentia, Mammalia) in the 
1 Mediterranean zone: biometric and morphological differentiation: application to Pleistocene

2 Moroccan fossils. Mammalia 70(1-2): 90-97.

3 Dobigny G, Baylac M and Denys C (2002) Geometric morphometrics, neural networks and

4 diagnosis of sibling Taterillus species (Rodentia, Gerbillinae). Biological Journal of the $5 \quad$ Linnean Society. Oxford University Press 77(3): 319-327.

6 Evin A, Cucchi T, Cardini A, Vidarsdottir US, Larson G and Dobney K (2013) The long and 7 winding road: identifying pig domestication through molar size and shape. Journal of $8 \quad$ Archaeological Science 40(1): 735-743.

9 Fabre P-H, Pagès M, Musser GG, Fitriana YS, Fjelds \aa J, Jennings A, et al. (2013) A new 10 genus of rodent from Wallacea (Rodentia: Muridae: Murinae: Rattini), and its implication for 11 biogeography and Indo-Pacific Rattini systematics. Zoological Journal of the Linnean Society. 12 Oxford University Press 169(2): 408-447.

13 Fischer JB (1829) Synopsis Mammalium. Stuttgart.

14 Fitzpatrick SM (2015) The pre-Columbian Caribbean: Colonization, population dispersal, and 15 island adaptations. PaleoAmerica 1(4): 305-331.

16 'Forsyth Major CI (1901) The musk-rat of Santa Lucia (Antilles). Annals and Magazine of $17 \quad$ Natural History Series 7(7): 204-206.

18 Friant M (1941) Notes anatomiques sur les Megalomys des Antilles. Bulletin de la Société zoologique de France 66: 122-129.

Friesen VL, Smith AL, Gomez-Diaz E, Bolton M, Furness RW, González-Solís J, et al. (2007) 21 Sympatric speciation by allochrony in a seabird. Proceedings of the National Academy of 22 Sciences 104(47): 18589-18594.

23 Genoways HH, Kwiecinski GG, Larsen PA, Pedersen SC, Larsen RJ, Hoffman JD, et al. (2010) 24 Bats of the Grenadine Islands, West Indies, and placement of Koopman's line. Chiroptera $25 \quad$ Neotropical 16(1): 529-549. 
1 Giovas CM (2018) Pre-Columbian Amerindian Lifeways at the Sabazan Site, Carriacou, West

2 Indies. The Journal of Island and Coastal Archaeology 13(2): 161-190.

3 Giovas CM (2019) The beasts at large-perennial questions and new paradigms for Caribbean

4 translocation research. Part I: Ethnozoogeography of mammals. Environmental Archaeology $5 \quad 24(2): 182-198$.

6 Giovas CM, Kamenov GD, Fitzpatrick SM and Krigbaum J (2016) Sr and Pb isotopic 7 investigation of mammal introductions: Pre-Columbian zoogeographic records from the Lesser 8 Antilles, West Indies. Journal of Archaeological Science 69: 39-53.

9 Giovas CM, LeFebvre MJ and Fitzpatrick SM (2012) New records for prehistoric introduction 10 of Neotropical mammals to the West Indies: evidence from Carriacou, Lesser Antilles. Journal 11 of Biogeography 39(3): 476-487.

12 Gittins R (1985) Canonical variate analysis. Canonical Analysis. Springer, 67-95.

13 Goodall CR (1995) Procrustes methods in the statistical analysis of shape revisited. Current 14 issues in statistical shape analysis 18-33.

15 Govoni G and Fielding D (2001) Paca (Agouti paca) and Agouti (Dasyprocta spp.)16 Minilivestock Production in the Amazonas State of Venezuela. Tropicultura 19: 56-60.

17 Grouard S (2001) Subsistance, systèmes techniques et gestion territoriale en milieu insulaire antillais précolombien: exploitation des vertébrés et des crustacés aux époques Saladoïdes et 19 Troumassoïdes de Guadeloupe (400 av. JC à 1500 ap. JC). Paris 10.

20 Grouard S (2004) Variation des stratégies de subsistance des Précolombiens à Hope Estate, 21 Saint-Martin (Petites Antilles), d'après l'analyse des restes des petits vertébrés. Petits Animaux et Sociétés Humaines. Du Complément Alimentaire aux Ressources Utilitaires 441-467.

23 Grouard S (2007) Modes de vie des Précolombiens des Antilles françaises. Synthèse des 24 données archéozoologiques. Les nouvelles de l'archéologie (108/109): 91-101. 
1 Grouard S (2010) Caribbean archaeozoology. Current Advances in Latin-American

2 Archaeozoology. International Council for Archaeozoology: Universidad de Buenos Aires,

3 Mexico 89-109.

4 Grouard S (2015) Peuplemens humains et animaux de la Caraïbe depuis 10000 ans. HDR,

$5 \quad$ Université de Provence-Aix-Marseille I.

6 Guilday JE (1972) Archaeological Evidence of Scalopus aquaticus in the Upper Ohio Valley.

7 Journal of Mammalogy 53(4): 905-907.

8 Guilday JE and Parmalee PW (1965) Animal remains from the Sheep Rock Shelter (36Hu1),

9 Huntingdon County, Pennsylvania. Pennsylvania Archaeologist 35(1): 34-49.

10 Hardouin J (1995) Minilivestock: from gathering to controlled production. Biodiversity \&

11 Conservation. Springer 4(3): 220-232.

12 Hedges SB (1999) Distribution patterns of amphibians in the West Indies. Patterns of

13 distribution of amphibians: a global perspective 211-254.

14 Hedges SB (2001) Biogeography of the West Indies: an overview. Biogeography of the West

15 Indies: patterns and perspectives 15-33.

16 Hedges SB and Heinicke MP (2007) Molecular phylogeny and biogeography of West Indian

17 frogs of the genus Leptodactylus (Anura, Leptodactylidae). Molecular Phylogenetics and 18 Evolution 44(1): 308-314.

19 Heinsohn TE (2003) Animal translocation: long-term human influences on the vertebrate 20 zoogeography of Australasia (natural dispersal versus ethnophoresy). Australian Zoologist $2132(3): 351-376$.

22 Heinsohn TE (2010) Marsupials as introduced species: Long-term anthropogenic expansion of 23 the marsupial frontier and its implications for zoogeographic interpretation. Altered ecologies:

24 Fire, climate and human influence on terrestrial landscapes 133-176. 
1 Henderson RW (1992) Consequences of predator introductions and habitat destruction on

2 amphibians and reptiles in the post-Columbus West Indies. Caribbean journal of science 28(1-

3 2): $1-10$.

4 Hofman CL, Bright AJ, Boomert A and Knippenberg S (2007) Island rhythms: the web of social

5 relationships and interaction networks in the Lesser Antillean archipelago between $400 \mathrm{BC}$ and

$6 \quad$ AD 1492. Latin American Antiquity 18(3): 243-268.

7 Hofman CL, Bright AJ and Hoogland ML (2006) Archipelagic resource procurement and

8 mobility in the northern Lesser Antilles: the view from a 3000-year-old tropical forest campsite

9 on Saba. Journal of Island \& Coastal Archaeology 1(2): 145-164.

10 Hofman CL, Bright AJ, Hoogland ML and Keegan WF (2008) Attractive ideas, desirable

11 goods: examining the Late Ceramic Age relationships between Greater and Lesser Antillean societies. The Journal of Island and Coastal Archaeology 3(1): 17-34.

Hofman CL and Hoogland ML (2011) Unravelling the multi-scale networks of mobility and

14 exchange in the pre-colonial circum-Caribbean. Communities in contact: Essays in archaeology, ethnohistory and ethnography of the Amerindian Circum-Caribbean 14-44.

16 Hopwood AT (1926) XLVI.-A fossil rice-rat from the Pleistocene of Barbuda. Journal of Natural History 17(99): 328-330.

Horst GR, Hoagland DB and Kilpatrick CW (2001) The mongoose in the West Indies: the biogeography and population biology of an introduced species. Biogeography of the West Indies. CRC Press, 435-450

21 Hulme-Beaman A, Claude J, Chaval Y, Evin A, Morand S, Vigne JD, et al. (2018a) Dental 22 Shape Variation and Phylogenetic Signal in the Rattini Tribe Species of Mainland Southeast Asia. Journal of Mammalian Evolution 1-12. 
1 Hulme-Beaman A, Cucchi T, Evin A, Searle JB and Dobney K (2018b) Exploring Rattus

2 praetor (Rodentia, Muridae) as a possible species complex using geometric morphometrics on

3 dental morphology. Mammalian Biology 92: 62-67.

4 Jansa SA, Barker FK and Heaney LR (2006) The pattern and timing of diversification of

5 Philippine endemic rodents: evidence from mitochondrial and nuclear gene sequences.

6 Systematic Biology. Oxford University Press 55(1): 73-88.

7 Jany I, Scanlon KM and Mauffret A (1990) Geological interpretation of combined Seabeam,

8 Gloria and seismic data from Anegada Passage (Virgin Islands, north Caribbean). Marine

9 Geophysical Researches 12(3): 173-196.

10 Kadmon $\mathrm{R}$ and Allouche $\mathrm{O}$ (2007) Integrating the effects of area, isolation, and habitat

11 heterogeneity on species diversity: a unification of island biogeography and niche theory. The American Naturalist 170(3): 443-454.

13 Kimura BK, LeFebvre MJ, deFrance SD, Knodel HI, Turner MS, Fitzsimmons NS, et al. (2016)

14 Origin of pre-Columbian guinea pigs from Caribbean archeological sites revealed through 15 genetic analysis. Journal of Archaeological Science: Reports 5: 442-452: 16 doi:10.1016/j.jasrep.2015.12.012.

17 Knippenberg S (2007) Stone artefact production and exchange among the Lesser Antilles. 18 Amsterdam University Press.

19 Laffoon JE, Hoogland ML, Davies GR and Hofman CL (2016) Human dietary assessment in 20 the Pre-colonial Lesser Antilles: New stable isotope evidence from Lavoutte, Saint Lucia. 21 Journal of Archaeological Science: Reports 5: 168-180.

22 Laffoon JE, Plomp E, Davies GR, Hoogland ML and Hofman CL (2015) The movement and 23 exchange of dogs in the prehistoric Caribbean: An isotopic investigation. International Journal 24 of Osteoarchaeology 25(4): 454-465. 
1 Laffoon JE, Rojas RV and Hofman CL (2013) Oxygen and carbon isotope analysis of human

2 dental enamel from the Caribbean: implications for investigating individual origins.

3 Archaeometry 55(4): 742-765.

4 LeFebvre MJ and deFrance SD (2014) Guinea Pigs in the Pre-Columbian West Indies. The 5 Journal of Island and Coastal Archaeology 9(1): 16-44: doi:10.1080/15564894.2013.861545.

6 LeFebvre MJ, DuChemin G, deFrance SD, Keegan WF and Walczesky K (2019) Bahamian 7 hutia (Geocapromys ingrahami) in the Lucayan Realm: pre-Columbian exploitation and 8 translocation. Environmental Archaeology 24(2): 115-131.

9 Lord E, Collins C, deFrance S, LeFebvre MJ and Matisoo-Smith E (2018) Complete 10 mitogenomes of ancient Caribbean Guinea pigs (Cavia porcellus). Journal of Archaeological 11 Science: Reports 17: 678-688.

12 Losos JB (2000) Ecological character displacement and the study of adaptation. Proceedings 13 of the National Academy of Sciences. National Acad Sciences 97(11): 5693-5695.

14 Losos JB and Ricklefs RE (2009) Adaptation and diversification on islands. Nature. Special 15 Features.

16 Louppe V, Herrel A, Pisanu B, Grouard S and Véron G (2020) Occupancy modelling of two 17 invasive carnivores in two Caribbean islands: implications for insular ecosystems. Journal of 18 Zoology.

19 Machado LF, Leite YL, Christoff AU and Giugliano LG (2014) Phylogeny and biogeography 20 of tetralophodont rodents of the tribe Oryzomyini (Cricetidae: Sigmodontinae). Zoologica 21 Scripta 43(2): 119-130.

22 MacPhee RDE and Flemming C (1999) Requiem Aeternam. Extinctions in near time. Springer, 23 $333-371$. 
1 Maestri R, Monteiro LR, Fornel R, de Freitas TRO and Patterson BD (2018) Geometric

2 morphometrics meets metacommunity ecology: environment and lineage distribution affects

3 spatial variation in shape. Ecography 41(1): 90-100.

4 McFarlane DA, Lundberg J and Maincent G (2014) New specimens of Amblyrhiza inundata 5 (Rodentia: Caviomorpha) from the Middle Pleistocene of Saint Barthélemy, French West 6 Indies. Caribbean Journal of Earth Science 47: 15-19.

7 McPhee RDE and Flemming C (1999) Requiem aeternam: the last five hundred years of 8 mammalian species extinctions. Extinctions in near time. Kluwer Academic/Plenum Publishers, $9 \quad$ New York, NY 333-371.

10 Miljutin A (2010) Notes on the external morphology, ecology, and origin of Megalomys 11 desmarestii (Sigmodontinae, Cricetidae, Rodentia), The extinct giant rat of Martinique Island, 12 Lesser Antilles. Estonian Journal of Ecology 59(3): 216-229.

13 Millien V (2006) Morphological evolution is accelerated among island mammals. PLoS biology $144(10)$.

15 Mistretta BA (2019) Grenada's extinct rice rats (Oryzomyini): Zooarchaeological evidence for 16 taxonomic diversity. Journal of Archaeological Science: Reports 24: 71-79.

17 Mol AAA (2006) Costly Giving, Giving Guaizas: Towards an Organic Model of the Exchange 18 of Social Valuables in the Late Ceramic Age Caribbean. Sidestone Press.

19 Nagorsen DW and Cardini A (2009) Tempo and mode of evolutionary divergence in modern 20 and Holocene Vancouver Island marmots (Marmota vancouverensis)(Mammalia, Rodentia). 21 Journal of Zoological Systematics and Evolutionary Research. Wiley Online Library 47(3): $22 \quad 258-267$.

23 Newsom LA and Wing ES (2004) On land and sea: Native American uses of biological 24 resources in the West Indies. University of Alabama Press. 
1 Pagán Jiménez JR, Rodríguez M, Baik LC and Storde YN (2005) La temprana introducción y

2 uso de algunas plantas domésticas, silvestres y cultivos en las Antillas precolombinas. Una

3 primera revaloración desde la perspectiva del 'arcaico'de Vieques y Puerto Rico. Dialogo

4 antropológico 3(10): 7-33.

5 Paradis E and Schliep K (2018) ape 5.0: an environment for modern phylogenetics and

6 evolutionary analyses in R. Bioinformatics $1: 3$.

7 Pinchon R (Robert) (1967) Quelques aspects de la nature aux Antilles. Available at:

8 http://agris.fao.org/agris-search/search.do?recordID=US201300591948.

9 Polly PD and Mock OB (2018) Heritability: the link between development and the 10 microevolution of molar tooth form. Historical Biology. Taylor \& Francis 30(1-2): 53-63.

11 Pregill GK, Steadman DW and Watters DR (1994) Late Quaternary vertebrate Faunas of the 12 Lesser Antilles: Historical components of Caribeean Biogeography. Carnegie Museum of

13 Natural History 30. Available at: http://archive.org/details/bulletinofcarneg3019carn.

14 R Core Team (2019) R: A language and environment for statistical computing. Vienna, Austria.

15 Available at: https://www.R-project.org.

16 Ray CE (1962) The oryzomyine rodents of the Antillean subregion: a thesis. PhD Thesis, 17 Harvard University.

18 Renaud S, Auffray J-C and Michaux J (2006) Conserved phenotypic variation patterns, 19 evolution along lines of least resistance, and departure due to selection in fossil rodents. 20 Evolution. Wiley Online Library 60(8): 1701-1717.

21 Renaud S, Michaux J, Jaeger J-J and Auffray J-C (1996) Fourier analysis applied to 22 Stephanomys (Rodentia, Muridae) molars: nonprogressive evolutionary pattern in a gradual 23 lineage. Paleobiology 22(02): 255-265. 
1 Ricklefs RE and Bermingham E (2007) The Causes of Evolutionary Radiations in

2 Archipelagoes: Passerine Birds in the Lesser Antilles. The American Naturalist 169(3): 285-

3 297: doi:10.1086/510730.

4 Rohlf FJ (2004) tpsDig-thin plate spline digitizer, version 1.40. State University of New York 5 at Stony Brook, New York.

6 Rohlf FJ and Slice D (1990) Extensions of the Procrustes method for the optimal 7 superimposition of landmarks. Systematic Biology 39(1): 40-59.

8 Roughgarden J (1995) Anolis lizards of the Caribbean: ecology, evolution, and plate tectonics.

9 Oxford University Press.

10 Rouse I and Faber Morse B (1999) Excavations at the Indian Creek Site, Antigua, West Indies.

11 Russell EL, Chiang LH and Braatz RD (2000) Canonical Variate Analysis. Data-driven

12 Methods for Fault Detection and Diagnosis in Chemical Processes. Springer, 81-95.

13 Saitou N and Nei M (1987) The neighbor-joining method: a new method for reconstructing 14 phylogenetic trees. Molecular biology and evolution 4(4): 406-425.

15 Schlager S (2013) Morpho: Calculations and visualisations related to Geometric 16 Morphometrics. $R$ package version 0.23 3: 195-220.

17 Scrucca L (2016) Genetic algorithms for subset selection in model-based clustering. 18 Unsupervised Learning Algorithms. Springer, 55-70.

19 Siegel PE (1989) Early ceramic population lifeways and adaptive strategies in the Caribbean.

20 British Archaeological Association.

21 Siegel PE, Jones JG, Pearsall DM, Dunning NP, Farrell P, Duncan NA, et al. (2015)

22 Paleoenvironmental evidence for first human colonization of the eastern Caribbean.

23 Quaternary Science Reviews 129: 275-295. 
1 Steadman DW, Pregill GK and Olson SL (1984) Fossil vertebrates from Antigua, Lesser

2 Antilles: Evidence for late Holocene human-caused extinctions in the West Indies. Proceedings

3 of the National Academy of Sciences 81(14): 4448-4451: doi:10.1073/pnas.81.14.4448.

4 Stoetzel E, Cornette R, Lalis A, Nicolas V, Cucchi T and Denys C (2017) Systematics and 5 evolution of the Meriones shawii/grandis complex (Rodentia, Gerbillinae) during the Late

6 Quaternary in northwestern Africa: Exploring the role of environmental and anthropogenic 7 changes. Quaternary Science Reviews. Elsevier 164: 199-216.

8 Stouvenot C and Randrianasolo A (2013) Matières premières lithiques des sites mésoindien et 9 néoindien de la Baie Orientale à Saint-Martin (Petites Antilles). Editions de la maison des 10 sciences de l'Homme.

11 Trouessart E-L (1885) Note sur le rat musqué ("Mus pilorides”) des Antilles, type du sous12 genre" Megalomys"(Trt) et la place de ce sous-genre dans le groupe des rats américains ou" 13 Hesperomyeae". G. Masson.

14 Turvey ST, Weksler M, Morris EL and Nokkert M (2010) Taxonomy, phylogeny, and diversity 15 of the extinct Lesser Antillean rice rats (Sigmodontinae: Oryzomyini), with description of a 16 new genus and species. Zoological Journal of the Linnean Society 160(4): 748-772.

17 Valenzuela-Lamas S, Baylac M, Cucchi T and Vigne J-D (2011) House mouse dispersal in Iron 18 Age Spain: a geometric morphometrics appraisal. Biological Journal of the Linnean Society 19 102(3): 483-497.

20 van Dam J (1996) Stephanodonty in fossil murids. Advances in morphometrics. Springer, 44921461.

22 Vázquez-Domínguez E, Garrido-Garduño T and Calixto-Pérez E (2020) Climate Change 23 Impact at the Genetic Level: Patterns in the Couesi's Rice Rat (Oryzomys couesi). 24 Conservation Genetics in Mammals. Springer, 301-329. 
1 Vickery KD, Theler JL and Shane III OC (2016) Archaeological Remains of the Rice Rat

2 (Oryzomys) as a Climatic Proxy in the American Midwest. The Wisconsin Archaeological 3 Society 97(2): 49-80.

4 Vigne J-D and Valladas H (1996) Small mammal fossil assemblages as indicators of 5 environmental change in northern Corsica during the last 2500 years. Journal of archaeological $6 \quad$ science 23(2): 199-215.

7 Whittaker RJ and Fernández-Palacios JM (2007) Island biogeography: ecology, evolution, and 8 conservation. Oxford University Press.

9 Wilkinson MJ, Marshall LG, Lundberg JG and Kreslavsky MH (2010) Megafan environments 10 in northern South America and their impact on Amazon Neogene aquatic ecosystems. 11 Amazonia, Landscape and Species Evolution: A Look into the Past. Wiley-Blackwell, Oxford $12 \quad 162-184$.

13 Wing ES (2001a) The sustainability of resources used by native Americans on four Caribbean 14 islands. International Journal of Osteoarchaeology 11(1-2): 112-126.

15 Wing ES (2001b) Native American use of animals in the Caribbean. Biogeography of the West 16 Indies: Patterns and Perspectives, Second Edition. CRC Press, 481-518. Wing ES and Wing SR (1995) Prehistoric ceramic age adaptation to varying diversity of animal resources along the West Indian archipelago. Journal of Ethnobiology 15: 119-148.

\section{Author contributions:}

Author contributions: AE and SG conceived the ideas; DB, KD, SG, SP and GR conducted the fieldwork and collected the material, KD and SG identified the archaeological bones; MD acquired the data; $\mathrm{MD}$ and $\mathrm{AE}$ performed the analyses; $\mathrm{MD}, \mathrm{AE}, \mathrm{SG}, \mathrm{VN}$, interpreted the results and MD led the writing with assistance from AE, SG and VN. 


\section{Table legend:}

2 Table 1 - Number of archaeological rice rat lower first molars studied, organized by chrono-cultural period,

3 archaeological site and island of origin.

4

\section{Figures legends:}

6 Figure 1 - Map of the Lesser Antilles archipelago. The seven islands investigated are highlighted and followed by

7 the number of archaeological rice rats (tribe Oryzomyini) teeth analyzed. The number of archaeological sites

8 studied are in brackets. Information about the sites can be found in Table 1. Grey shadows indicate the geological

9 banks exposed during the Pleistocene (Hedges, 2001; McPhee and Flemming, 1999; Pregill et al., 1994). Dashed

10 lines in the North mark the Anegada passage (Jany et al., 1990) and in the South Koopman's Line (Genoways et 11 al., 2010).

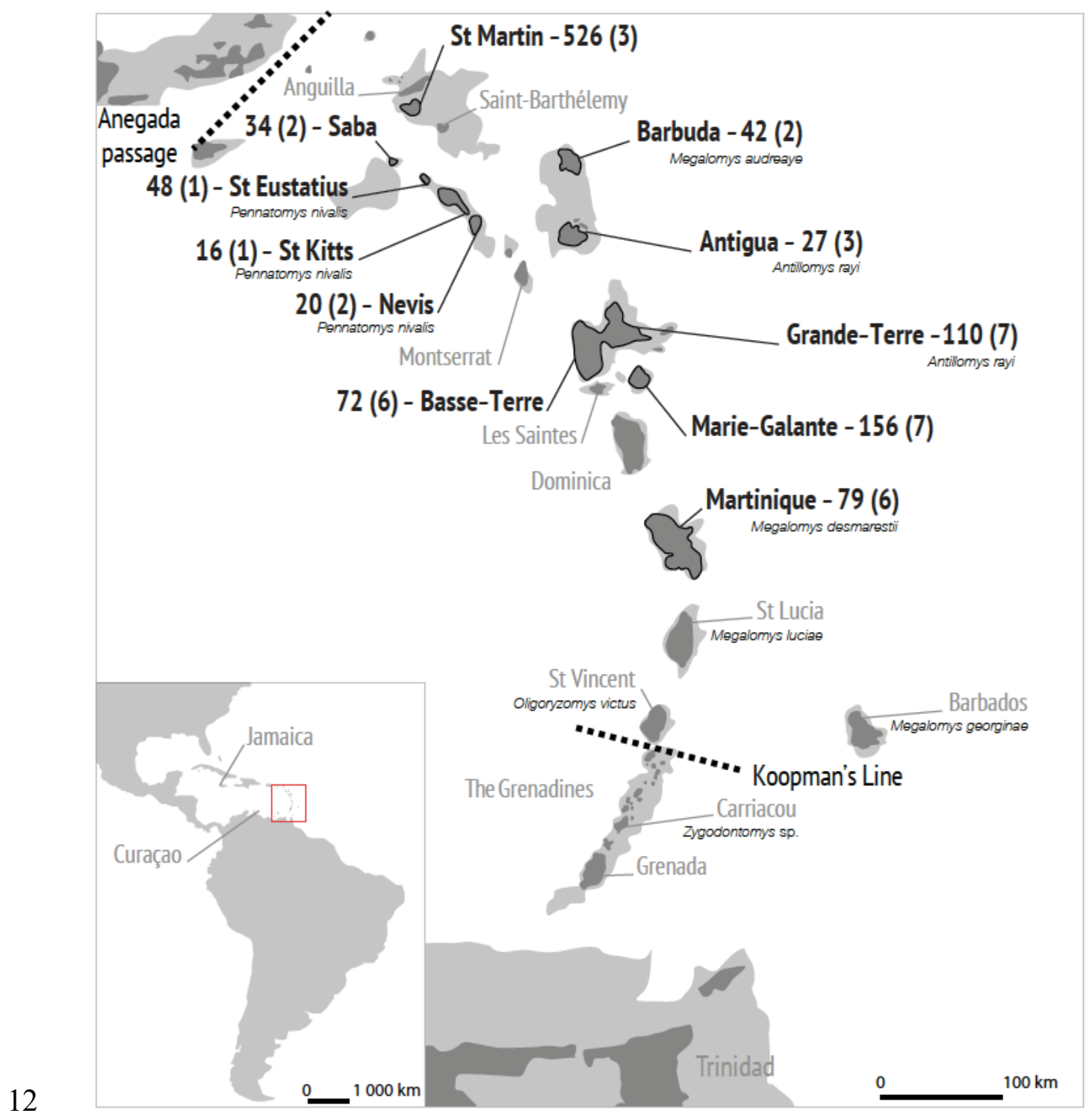


1 Figure 2 - Left: Occlusal view of a first lower molar of a Lesser Antillean rice rat (specimen SRA-Guadeloupe-

2 HE-089-D from Hope Estate, Saint-Martin). Right: Geometric morphometric protocol including one landmark

3 (large yellow dot) and 65 sliding semi-landmarks along the outside curvature of the tooth, recorded in a clockwise 4 direction.

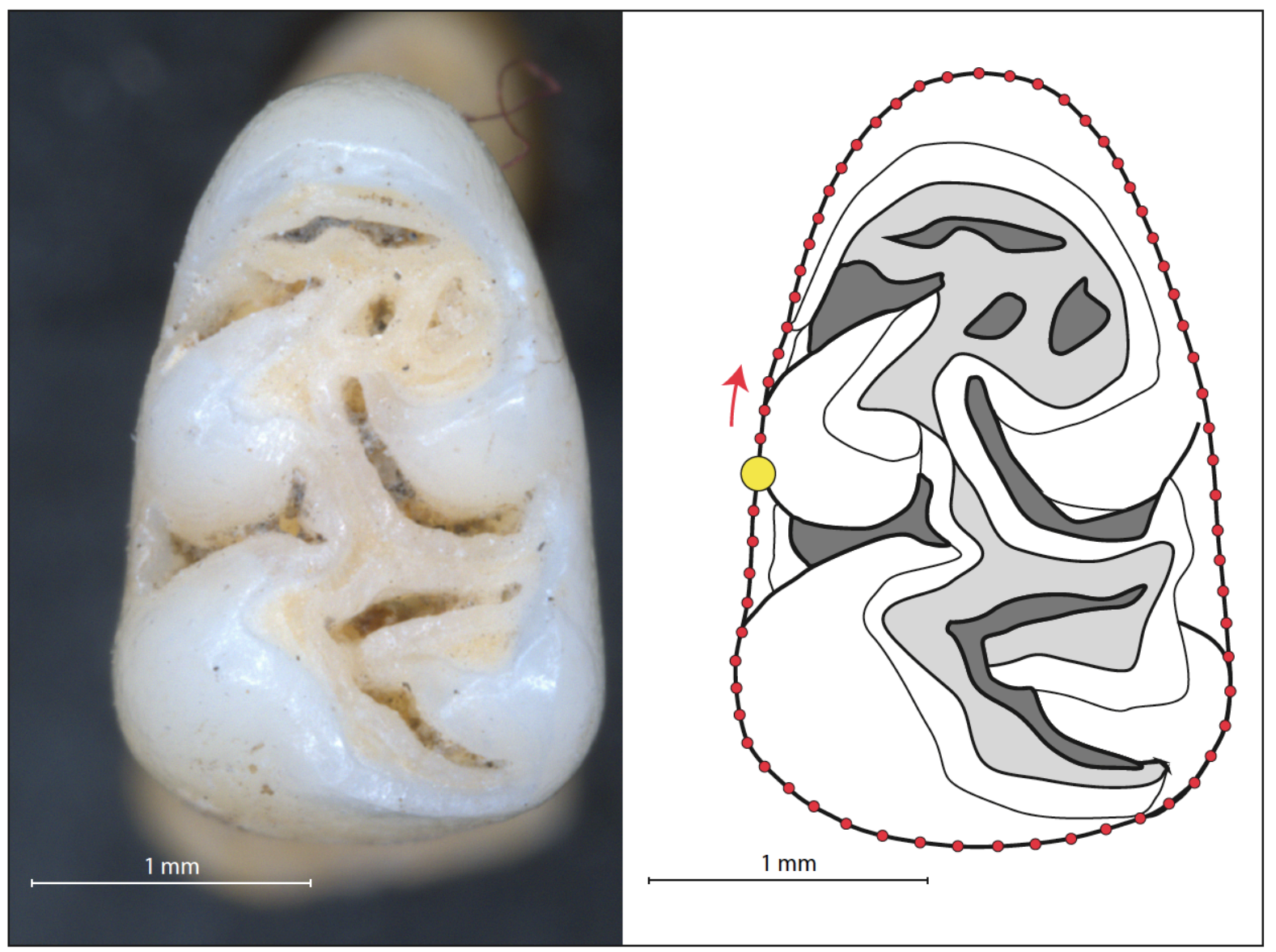


1 Figure 3 - Size variation between rice rat populations of the Lesser Antilles. Boxplots of the log-transformed centroid size of the lower M1. Specimens were grouped by island, site and chronological occupation phase. In

3 light blue: Early Ceramic Age A, dark blue: Early Ceramic Age B, pink: Late Ceramic Age A, red: Late Ceramic Age B. SE: Saint-Eustatius, SK: Saint-Kitts, NEV.: Nevis, ANT.: Antigua, BAR.: Barbuda. The islands names are colored according to the three shape clusters identified (Fig. 4) (purple: Northern islands, yellow: Central islands, green: Southern island).

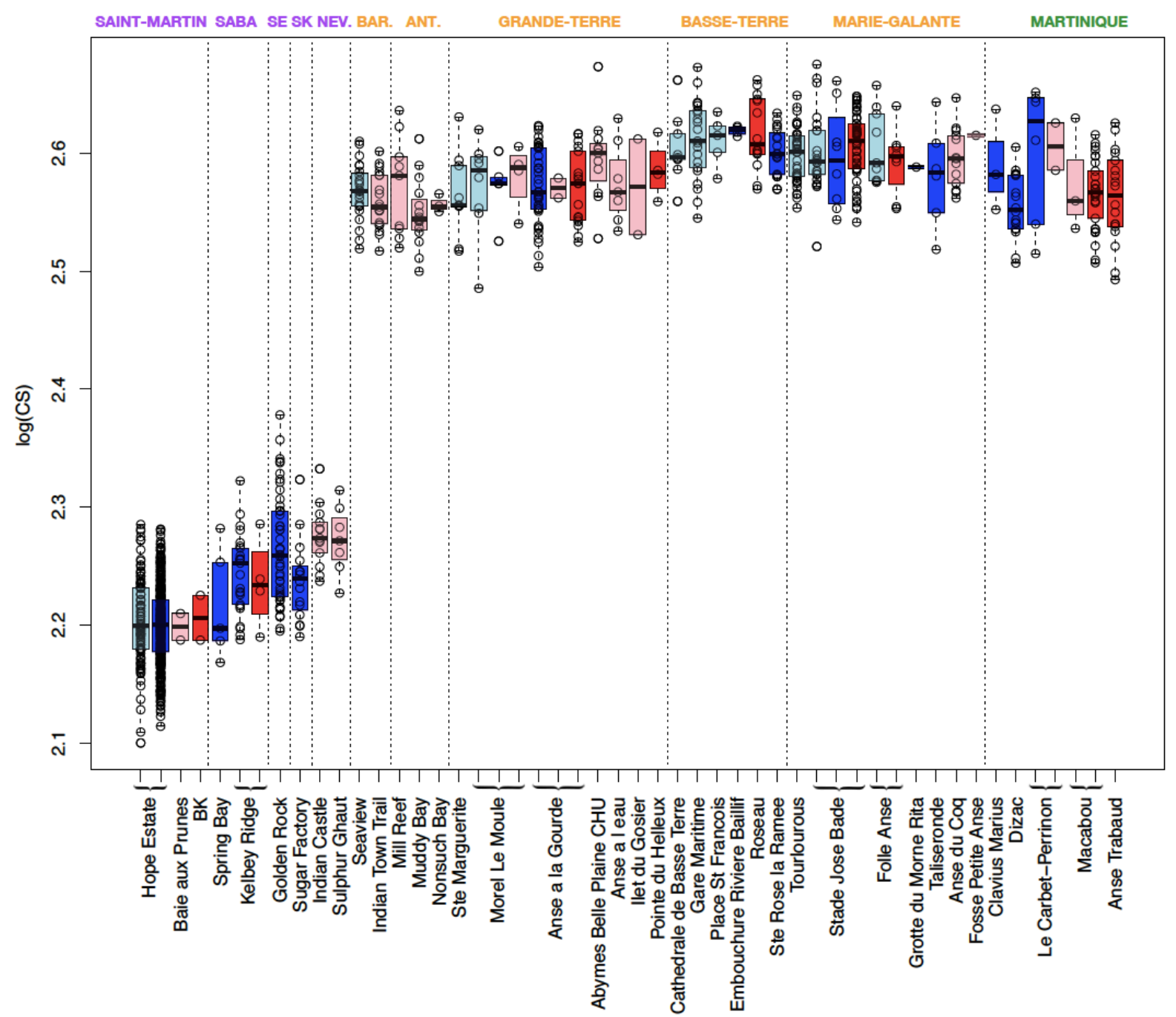


1 Figure 4 - A. Phenotypic relationship between sites across the Lesser Antilles. Mean branch lengths neighbor-

2 joining network of the bootstraped Mahalanobis distances (1000 replicates) with mention of the bootstrap

3 percentages above $50 \%$. Only sites with more than 10 specimens were included. Island names are colored by their

4 geographic and morphometrical cluster attribution (purple: Northern islands, yellow: Central islands, green:

5 Southern islands). B. Map of the studied islands colored by the three shape clusters identified.

6

7 Figure 5 - Phenotypic relationship between sites of the Northern islands. Mean branch lengths neighbor-

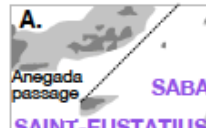
SAINT-KITTS

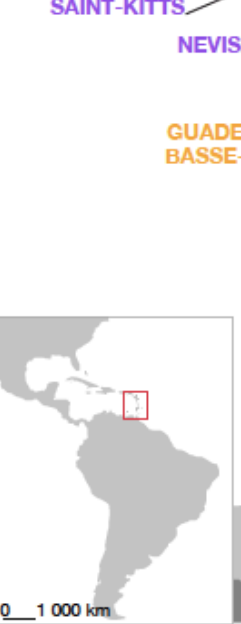

SAINT-MARTIN
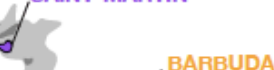

OS ANTIGUA

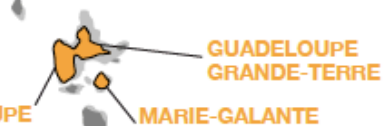

9
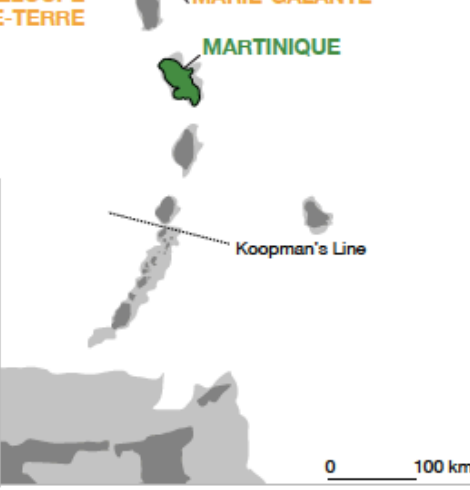

B.
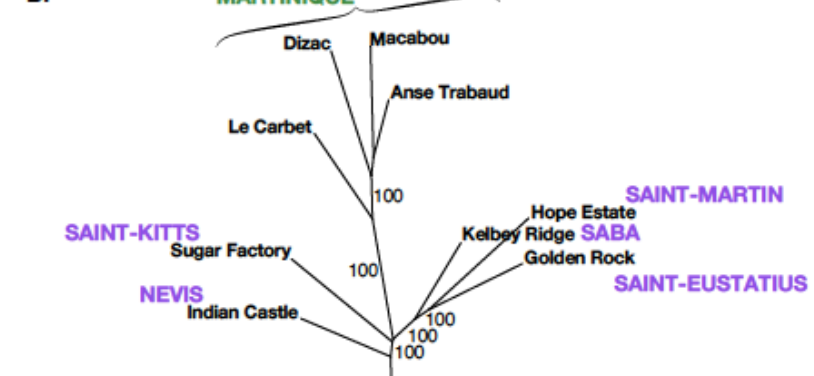

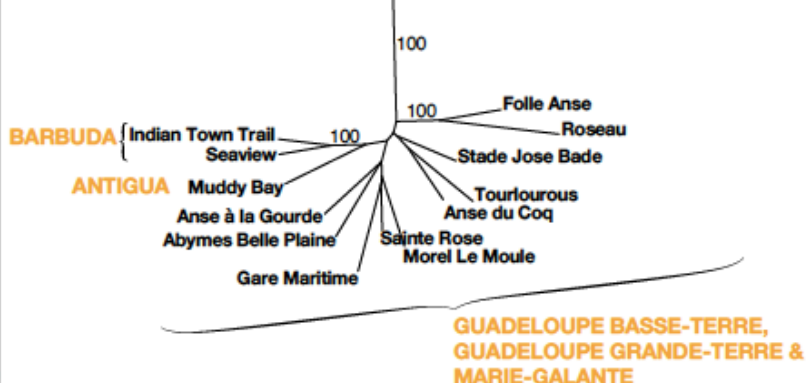

MARIE-GALANTE

8 joining network of the bootstraped Mahalanobis distances (1000 replicates) with mention of the bootstrap

9 percentages above $50 \%$. Site names are colored by chronological occupation phases (light blue: Early Ceramic A,

10 dark blue: Early Ceramic B, pink: Late Ceramic A, red: Late Ceramic B). Only sites with more than 10 specimens were included.

SAINT-KITTS

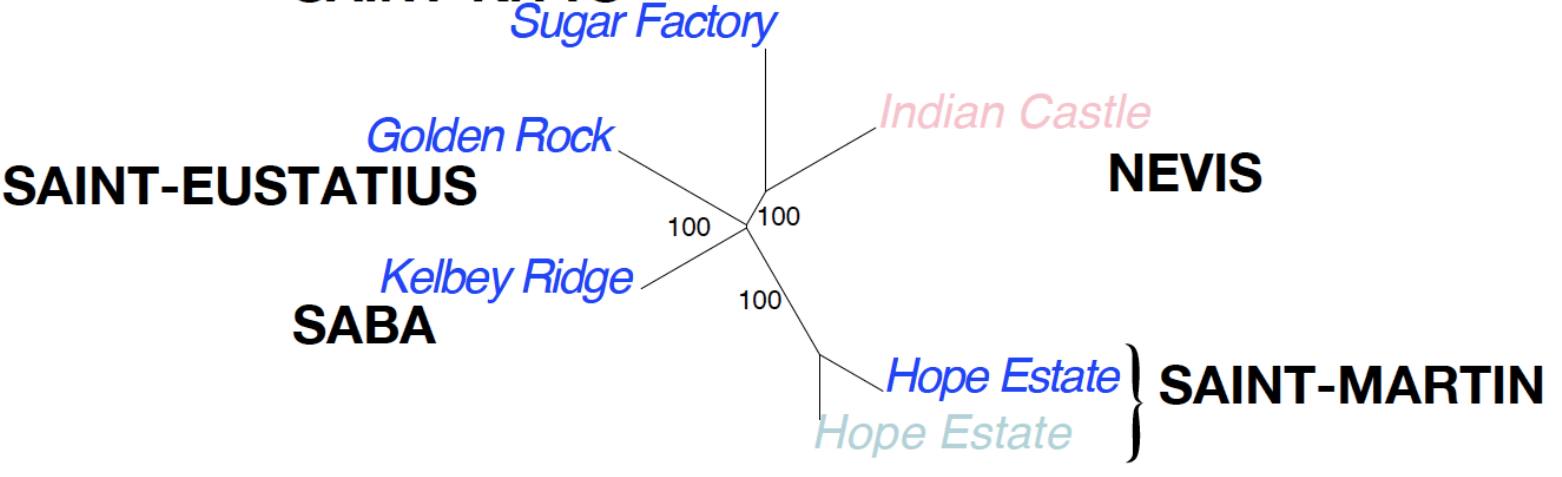


1 Figure 6 - Phenotypic relationship between sites of the Central islands. Mean branch lengths neighbor-joining network of the bootstraped Mahalanobis distances (1000 replicates) with mention of the bootstrap percentages

3 above $50 \%$. Site names are colored by chronological occupation phases (light blue: Early Ceramic A, dark blue:

4 Early Ceramic B, pink: Late Ceramic A, red: Late Ceramic B). M.G.: Marie-Galante, B.T.: Guadeloupe Basse-

5 Terre, GT: Guadeloupe Grande-Terre. Only sites with more than 10 specimens were included.

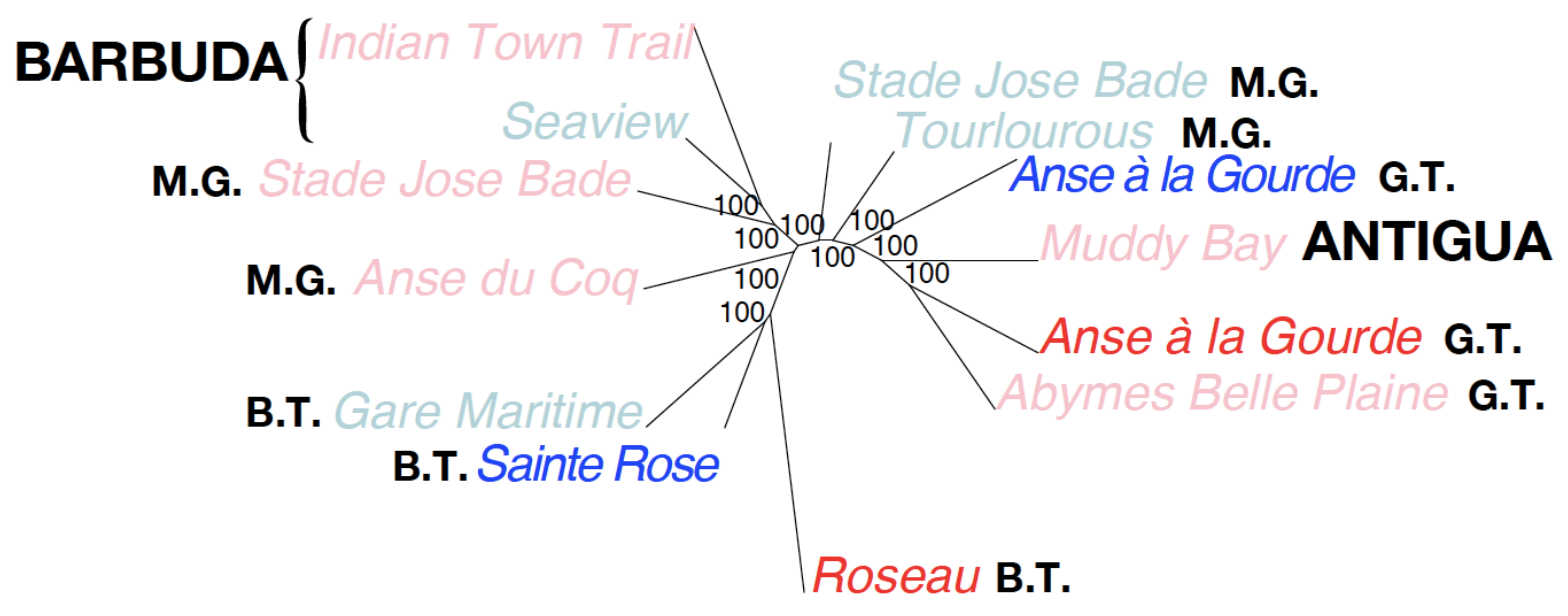

